\title{
The Effect of Packaging Types on The Organoleptic Properties of Instant Ganyong Yellow Rice
}

\author{
Lilis Sulandari, Lucia Tri Pangesthi \\ Department of Home Economics \\ Universitas Negeri Surabaya \\ Surabaya, Indonesia \\ lilissulandari@unesa.ac.id
}

\begin{abstract}
The effect of packaging types: aluminium foil (Al foil), nylon, and oriented polypropylene combined with vacuum metallized oriented polypropylene (OPP-VMOPP) on the organoleptic properties of instant ganyong yellow rice was analyzed. The results showed that the type of packaging produced different effects on the organoleptic properties during 12 weeks of storage (color, shape, and aroma), as well as in preferences of consumers. It was reported that the best packaging for instant ganyong yellow rice was aluminium foil.
\end{abstract}

Keywords-Instant gayong yellow rice; Al foil; Nylon; OPPVMOPP; organoleptic properties

\section{INTRODUCTION}

Yellow rice is a yellow-colored rice made from turmeric extract, a distinctive flavor derived from the spices used and has a savoury taste. According to [1] yellow rice is cooked rice by using coconut milk, salt, salam leaves, and turmeric. The coconut milk has a sense of fat and is used as a tasting flavor, so the cuisine becomes savoury [2]. In this study yellow rice is made from a mixture of rice and ganyong tubers (Canna edulis, Ker). Based on sources from the Directorate of Nutrition Department of Health, every 100 grams of ganyong consists of $95.00 \mathrm{kcal} ; 22,60 \mathrm{~g}$ carbohydrate; $1.00 \mathrm{~g}$ protein; $0.11 \mathrm{~g}$ fat; $75,00 \mathrm{~g}$ water; $21.00 \mathrm{~g}$ calcium; 75,00 g phosphorus; $1.90 \mathrm{mg}$ of iron; 0.10mg Vitamin B1; $10.00 \mathrm{mg}$ Vitamin C. Ganyong tubers contains $11.70 \%$ inulin and puree ganyong contains $23.63 \%$ inulin [3].

Advantage, making yellow rice is able to cover the brown color of the tubers. Further [4] mentions turmeric containing $2.5-6 \%$ orange yellow curcumin pigment. Curcumin in addition to having an orange yellow color also contributes to the character of spiciness that is soft on the spice. The liquid used in making yellow rice is coconut milk. Coconut milk gives a savoury flavor, combined with the flavor of seasoning makes delicious yellow rice different. However, the use of coconut milk can cause easily damaged yellow rice. Futher [2] mentions that coconut milk is usually survived less than ten hours at room temperature $25^{\circ}-30^{\circ} \mathrm{C}$ and can withstand more than twenty-four hours in the refrigerator.

Efforts are made by making instant ganyong yellow rice for extending its shelf life. According to [5] instant rice product has been growing rapidly in developed countries such as the USA and Japan, among others Sage V food the ripening time of 5 minutes with hot water brewed; cup rice from Nissin Foods Company, which is a 5-minute ripening instant rice with uncle's trademark Ben ripening of 1.5 minutes in the microwave. Instant rice uncle's Ben is not as instant rice in general that through the process of freezing and drying but this rice as regular rice is preserved then heated in the microwave if it will be consumed.

Instant products require specified packaging to keep products easily stored and distributed. There specified packaging namely aluminium foil, nylon (plastic) and oriented polypropylene OPP) with vacuum metallise oriented polypropylene (OPP-VMOPP). The aluminium foil packaging is made from metal in the form of solid and thin aluminium sheets with a thickness of $\leq 0.15 \mathrm{~mm}$ is hermetic, flexible, and opaque. The thickness of the material determines its protective properties, if thin the packaging can be traversed by the gas and steam, aluminium foil can not be passed gas and water vapour at a thickness of more than $25.4 \mu \mathrm{m}$. The aluminium foil packaging has a lower water vapour and oxygen transmission rate and is more heat resistant than the PP and LDPE types [6].

Bioriented polyamide (BOPA) better known as Nylon Bioriented (BO-Ny) or nylon (ONY). Properties and characte ristics: density $1.15 \mathrm{~g} / \mathrm{cm} 3$, general thick- ness $15 \mathrm{mcr}$, good transparency, very soft and flexible, good resistance against puncture and friction, stable to temperature changes, good as gas and aroma retardant, good resistance and low temperature, against abrasion and impact, absorb water vapor, resistant to oil and chemicals, and a good barrier to scent. Protective properties (Barrier) a plastic material, because the metal foil is not transparent and the glass is not flexible for flexible packaging commonly used plastic materials (polymer). All materials, except glass and metal, drivable (permeable) by steam, air and other gases. Criteria for High Barrier Material: OTR $<1 \mathrm{cc} / 100 \mathrm{inch}^{2} /$ day or OTR $<15.5 \mathrm{cc} / \mathrm{m}^{2} /$ day. The definition of "OTR (oxygen transmission rate) is the speed of oxygen gas penetrates through the film on conditions of temperature and relative humidity, under conditions steady state. The value is expressed in cc/m $/ 24 \mathrm{hr}$. The standard test conditions are $23^{\circ} \mathrm{C}, 0 \% \mathrm{RH}[7]$.

Oriented polypropylene (OPP) derived from propylene polymerization reaction with the appropriate conditions and catalysts. The main key in the process of making OPP is the process of withdrawal and stretching to form the molecular 
orientation. OPP characteristics are resistant to the organic solvent, however, solvent aromatics, such as toluene and benzene, can cause OPP to expand (swell). High temperatures can improve the elongation properties of OPP due to the thermoplastic properties of the material. OPP properties are highly transparent, the excellent barrier for moisture, good temperature resistance, good mechanical properties, and cheaper price than other films. VMOPP is an OPP that undergoes the metalizing process. Metallizing purpo-se; metallized films can improve penetrating resistance to water vapour, aroma and gas, as decoration, and light resistance. VMOPP has a water vapor transmission rate (WVTR) of $3 \mathrm{~g} / \mathrm{m}^{2} /$ day and OTR (oxygen transmission rate) of $300 \mathrm{cc} / \mathrm{m} 2 / 24 \mathrm{hr}$. This study aims to determine the effects of this type of packaging on the organoleptic properties of instant ganyong yellow rice, including color, shape, aroma and favourite level and nutritional content of instant ganyong yellow rice.

\section{METHODS}

\section{A. Materials}

The materials used in the making of yellow rice: rice Kingfish Catfish branded packed by CV. The Earth Imagery from Indonesia, ganyong tubers (Canna edulis Kerr), coconut milk, spices: salt, turmeric, salam leaves, lime leaves, lime juice and lemon grass. Three types of packaging, including aluminium foil (Al foil), Nylon and the combination of oriented polypropylene (OPP) and vacuum metallise OPP (OPP-VMOPP). Packed aluminum foil bag, PE /ALU /SPE-50 type, $\mathrm{WxH}=80 \times 120 \mathrm{~mm}$. Type of Nylon structure: Nylon/ SPE70, WxHxD = $95 \times 250 \times 60 \mathrm{~mm}$. The combined packaging used was bag, Tras-Met type, $\mathrm{W} \times \mathrm{H}=130 \times 210 \mathrm{~mm}$, front structure: OPP / SPE-70, and rear structure: VMOPP/SPE70. All packaging brand K pack with code 07 was obtained from Toko Kemasan Kita Surabaya Indonesia.

\section{B. Equipment}

Equipment used were the equipment for making instant ganyong yellow rice consist of rice cooking utensils, freezer, dryer cabinet, as well as organoleptic test equipment.

\section{Making of Instant Ganyong Yellow Rice}

Making instant ganyong yellow rice refer to [8]. Ganyong tubers were washed and then boiled for 45 minutes. Ganyong tubers were peeled and shredded into puree ganyong. Rice and all materials were washed. Coconut and turmeric were grated, mixed and took milk coconut. Comparison of oil and water was used (1:1). All the ingredients were mixed and boiled, then rice was inserted and stirred until coconut milk absorbed (called aron rice). Aron rice removed and closed for 15 minutes. Aron rice was steamed for 30 minutes and ganyong yellow rice was obtained. Then, ganyong yellow rice was frozen for 24 hours. Frozen yellow rice left at room temperature for 10 minutes while separated granular. Ganyong yellow rice grains were dried at $60{ }^{\circ} \mathrm{C}$ for 4 hours. It was called instant ganyong yellow rice.

\section{RESULT AND DISCUSSION}

\section{A. Color of Instant Ganyong YellowRice}

The average value of the organoleptic test of instant ganyong yellow rice color with 3 different types of packaging during 12 weeks storage ranged from 1.71-4.00 with the criterion of yellow dull, slightly yellow dull, yellow enough and yellow. Average of instant ganyong yellow rice color values with $\mathrm{Al}$ foil, Nylon and OPPVMOPP packaging were respectively $3.36,2.74$ and 2.80 . The average instant ganyong yellow rice color value packed with 3 different packaging materials at room temperature storage for 12 weeks was presented in Fig.1.

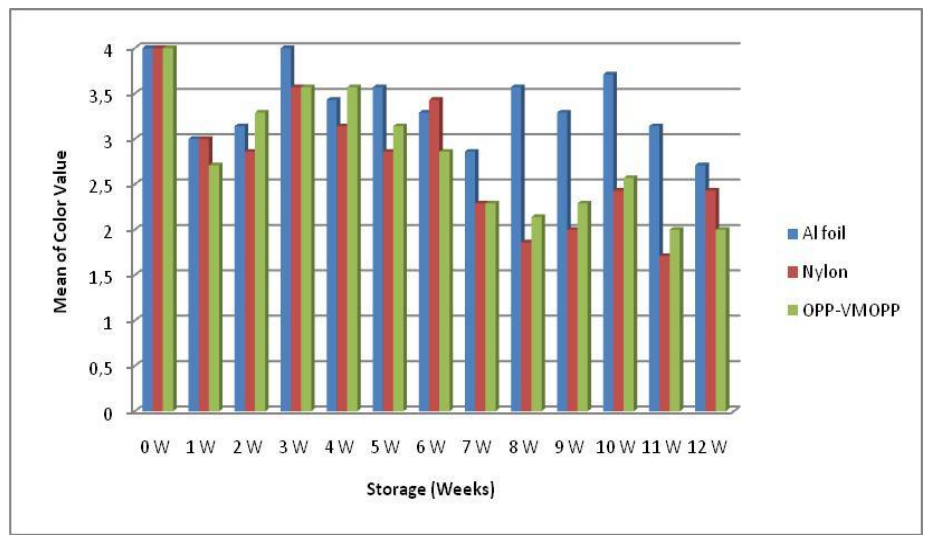

Fig. 1. Average of instant ganyong yellow rice color values with 3 types of packaging during 12 weeks storage at room temperature

The value of significance of each type of packaging was $0.007 ; 0,000$ and 0,000. Further test results Multiple Comparison Test to determine the differences in types of packaging material effect on the color instant ganyong yellow rice during 12 weeks of storage were presented in Table 1.

Table 1. shows instant ganyong yellow g rice packed with $\mathrm{Al}$ foil at 0 weeks storage until 11 weeks had a yellow color, and began to change at 12 weeks storage, becoming quite yellow. Instant ganyong yellow rice packed with Nylon at 0 weeks to 6 weeks storage has a yellow color, and 7-week storage starts turning slightly dull yellow. Instant ganyong yellow rice packed with OPP-VMOPP at 0 weeks to 6 weeks storage had a yellow color and began to turn slightly dull yellow at 7 weeks storage.

The existence of the color difference of instant ganyong yellow rice packed with Al foil, Nylon and OPPVMOPP showed ganyong the difference in packaging ability to hold oxygen. The presence of oxygen in the pack is related to the oxidation activity of the phenolase enzyme that causes the brownish color derived from the use of puree ganyong. Puree ganyong has a greyish white color until brownish, due to the activity of phenolase enzyme in fresh ganyong tubers. When the puree ganyong mixed with the rice in the making of yellow rice, the color became slightly dull yellow. According to [8] the transmission rate of oxygen gas (OTR) in Nylon $90\left(\mathrm{~cm}^{3} / \mathrm{m}^{2} /\right.$ day), while the OTR Al foil value is $0-1 \mathrm{~cm}^{3} / \mathrm{m}^{2} /$ day. OPP packaging has 
an oxygen transmission rate (OTR) higher than that of Nylon, but when combined with VMOPP it is thought to be capable of inhibiting oxidation by oxygen from the air greater than nylon.

Yellow color changes allegedly related to the influence of light that can penetrate on the packaging. The curcumin found in turmeric as yellow rice spice has a heat stable property, but will become pale by light.
Friedman test results indicate the type of packing $\mathrm{Al}$ foil, Nylon and OPP-VMOPP gave effect to the form of instant ganyong yellow rice during 12 weeks storage at room temperature. The value of significance of each type of packaging is $0.007 ; 0.008$ and 0.030 . Further test results of Multiple Comparison Test to determined differences in the effect of types of packaging material to shape instant ganyong yellow rice during 12 weeks of storage were presented in Table 2.

TABLE I. MULTIPLE COMPARISON TEST OF INSTANT GANYONG YELLOW RICE COLOR WITH 3 TYPES OF PACKAGING FOR STORAGE 12 WEEKS AT ROOM TEMPERATURE

\begin{tabular}{|c|c|c|c|c|c|c|c|c|c|}
\hline \multirow[t]{2}{*}{ Storage Duration } & \multicolumn{3}{|c|}{ Al foil } & \multicolumn{3}{|c|}{ Nylon } & \multicolumn{3}{|c|}{ OPP-VMOPP } \\
\hline & Average & $\begin{array}{c}\text { Total } \\
\text { Ranking }\end{array}$ & Notation & Average & $\begin{array}{c}\text { Total } \\
\text { Ranking }\end{array}$ & Notation & Average & $\begin{array}{c}\text { Total } \\
\text { Ranking }\end{array}$ & Notation \\
\hline 0 Week & 4.00 & 68 & $\mathrm{bc}$ & 4.00 & 82.5 & $\mathrm{e}$ & 4.00 & 82 & $\mathrm{e}$ \\
\hline 1 Week & 3.00 & 40 & $a b c$ & 3.00 & 54 & abcde & 2.71 & 50 & abcde \\
\hline 2 Weeks & 3.14 & 41 & $a b c$ & 2.86 & 52.5 & abcde & 3.29 & 64 & bcde \\
\hline 3 Weeks & 4.00 & 68 & $\mathrm{c}$ & 3.57 & 72 & de & 3.57 & 54 & $\mathrm{a}$ \\
\hline 4 Weeks & 3.43 & 52.5 & $a b c$ & 3.14 & 61.5 & bcde & 3.57 & 72.5 & de \\
\hline 5 Weeks & 3.57 & 55 & $a b c$ & 2.86 & 54 & abcde & 3.14 & 59.5 & abcde \\
\hline 6 Weeks & 3.29 & 47.5 & $a b c$ & 3.43 & 68 & cde & 2.86 & 50 & abcde \\
\hline 7 Weeks & 2.86 & 35.5 & $a b c$ & 2.29 & 38.5 & $a b c d$ & 2.29 & 32 & $a b$ \\
\hline 8 Weeks & 3.57 & 55 & $a b c$ & 1.86 & 22.5 & $\mathrm{a}$ & 2.14 & 26 & $\mathrm{a}$ \\
\hline 9 Weeks & 3.29 & 47.5 & $a b c$ & 2.00 & 27.5 & $a b$ & 2.29 & 32 & $a b$ \\
\hline 10 Weeks & 3.71 & 59 & $a b c$ & 2.43 & 40.5 & $a b c d$ & 2.57 & 41.5 & $a b c d$ \\
\hline 11 Weeks & 3.14 & 40.5 & $\mathrm{abc}$ & 1.71 & 23 & $\mathrm{a}$ & 2.00 & 27 & $\mathrm{a}$ \\
\hline 12 Weeks & 2.71 & 27.5 & $\mathrm{a}$ & 2.43 & 40.5 & $\mathrm{abcd}$ & 2.00 & 27 & $\mathrm{a}$ \\
\hline
\end{tabular}

Further [9] mentions turmeric containing 2.5-6\% pigment curcumin orange yellow. In addition to curcumin having an orange yellow color also contributes to the character of spiciness that is soft on the spice. Curcumin is stable against heat but becomes pale quickly due to the influence of light. This is consistent with the results of the study, that $\mathrm{Al}$ foil packaging is an opaque package, while Nylon and OPPVMOPP can be penetrated light so yellow ganyong rice instantly packed $\mathrm{Al}$ foil yellow is more resistant to 11 weeks storage, followed by packaging OPP- VMOPP and Nylon. OPP-VMOPP is a package that only one side can be penetrated light, while Nyon all sides can be penetrated by light.

\section{B. Shape of Instant Ganyong Yellow Rice}

The average value of organoleptic test of instant ganyong yellow rice with 3 different types of packaging during 12 weeks storage ranged from 2.57-4.00 with the criteria of shape assessment there are 4 levels, namely: not rolled (between grains sticking together and forming big blobs), many are broken; less grassy (between the grains sticking together and forming small clumps), slightly broken, the shape was quite grained (between the grains slightly stuck but not clot), quite intact and unbound (between grains not sticking together) and whole. The average value of instant ganyong yellow rice form with the packaging of $\mathrm{Al}$ foil, Nylon and OPP-VMOPP respectively $3.58 ; 3.43$ and 3.36 . The average instant ganyong yellow rice color value packed with 3 different packaging materials at room temperature storage for 12 weeks was presented in Fig. 2.

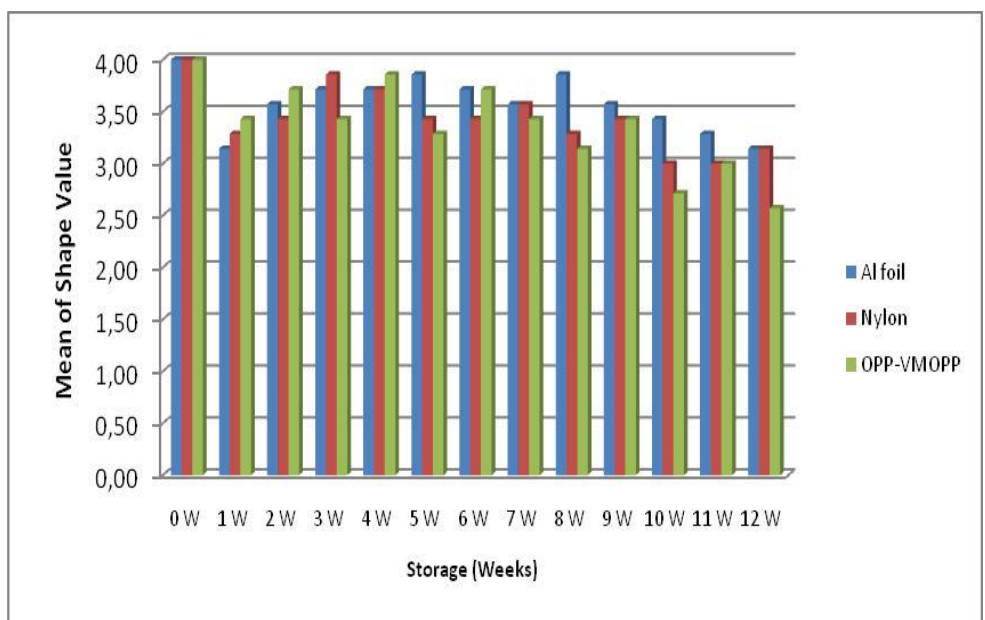

Fig. 2. Average of instant ganyong yellow rice shape value with 3 types of packaging during 12 weeks storageat room temperature

Table 2. Shows instant ganyong yellow rice packed with Nylon at 0 weeks storage had a grainy shape (between grains not sticking together) and whole. Starting from 1 week to 12 weeks of instant ganyong yellow rice had the same shape, just a roll (between the grains slightly sticking but not clot), and quite intact. Instant ganyong yellow rice packaged with OPPVMOPP had the same shape as Nylon packaging. On a weekly grain-shaped storage (between grains not sticking together) and intact, the storage of 1 to 12 weeks is fairly rounded (between the grains slightly attached but not clump) 
TABLE II. MULTIPLE COMPARISON TEST RESULTS OF INSTANT GANYONG YELLOW RICE SHAPE WITH 3 TYPES OF PACKAGING FOR STORAGE 12 WEEKS AT ROOM TEMPERATURE

\begin{tabular}{|c|c|c|c|c|c|c|}
\hline \multirow[b]{2}{*}{ Storage Duration } & \multicolumn{3}{|c|}{ Nylon } & \multicolumn{3}{|c|}{ OPP-VMOPP } \\
\hline & Average & $\begin{array}{c}\text { Total } \\
\text { Ranking }\end{array}$ & Notation & Average & $\begin{array}{c}\text { Total } \\
\text { Ranking }\end{array}$ & Notation \\
\hline 0 week & 4.00 & 70 & $\mathrm{~b}$ & 4.00 & 70.5 & $\mathrm{e}$ \\
\hline 1 week & 3.29 & 43 & $a b$ & 3.43 & 52.5 & abcde \\
\hline 2 weeks & 3.43 & 49.5 & $a b$ & 3.71 & 61.5 & bcde \\
\hline 3 weeks & 3.86 & 66 & $a b$ & 3.43 & 49.5 & de \\
\hline 4 weeks & 3.71 & 60.5 & $a b$ & 3.86 & 67.5 & cde \\
\hline 5 weeks & 3.43 & 47.5 & $a b$ & 3.29 & 47.5 & abcde \\
\hline 6 weeks & 3.43 & 47.5 & $a b$ & 3.71 & 61.5 & cde \\
\hline 7 weeks & 3.57 & 54.5 & $a b$ & 3.43 & 49.5 & bcde \\
\hline 8 weeks & 3.29 & 43 & $a b$ & 3.14 & 38 & abcde \\
\hline 9 weeks & 3.43 & 49.5 & $a b$ & 3.43 & 52.5 & abcde \\
\hline 10 weeks & 3.00 & 32.5 & $\mathrm{a}$ & 2.71 & 29.5 & $\mathrm{abc}$ \\
\hline 11 weeks & 3.00 & 34 & $a b$ & 3.00 & 37 & abcde \\
\hline 12 weeks & 3.14 & 39.5 & $a b$ & 2.57 & 21 & $\mathrm{a}$ \\
\hline
\end{tabular}

and intact enough. However, judging from the average value of instant ganyong yellow rice form larger on Nylon packaging compared with OPP-VMOPP packaging.

This showed the ability to resist the nylon greater impact than the packaging OPP-VMOPP. According to [7] Nylon (ONy) has a resistance to abrasion and impact (impact).

Instant ganyong yellow rice packed with $\mathrm{Al}$ foil had an average value of 3.14-4.00, based on Friedman test showed no difference. Criteria shape of instant ganyong yellow rice with Al foil packaging was grainy (between grains not stick together) and whole. The average value of instant yellow ganyong with packed $\mathrm{Al}$ foil is bigger than nylon and OPPVMOPP. This indicated that Al foil packaging has the ability to withstand impact from outside higher than nylon and OPPVMOPP so that the shape of instant ganyong yellow rice was packed relatively stable up to 12 weeks storage.

\section{Aroma of Instant Ganyong Yellow Rice}

Average test value of organoleptic aroma of instant ganyong yellow rice with 3 different types of packaging during 12 weeks storage ranged from 1.43 to 4.00 with the scoring criteria there were 4 levels, namely: not typical yellow rice (distorted, somewhat rancid); less typical flavored yellow rice; quite typical flavored yellow rice and flavored typical yellow rice. The average value of instant ganyong yellow rice aroma with the packaging of $\mathrm{Al}$ foil, Nylon and OPP-VMOPP respectively; 3,86, 3.36 and 3.24. The average value of instant ganyong yellow rice aroma packed with 3 different packaging materials at room temperature storage for 12 weeks was presented in Fig. 3.

Friedman test results show the type of $\mathrm{Al}$ foil packaging, did not give effect to the aroma of instant ganyong yellow rice during 12 weeks storage at room temperature, while the packaging of Nylon and OPP-VMOPP gave effect to the instant ganyong yellow rice aroma during 12 weeks storage at room temperature. The significance value of the Nylon and OPP-VMOPP packaging types was 0.000 . Further test results Multiple Comparison Test to determine the differences in types of packaging material influence on the aroma of instant ganyong yellow $\mathrm{t}$ rice during 12 weeks of storage were presented in Table 3.

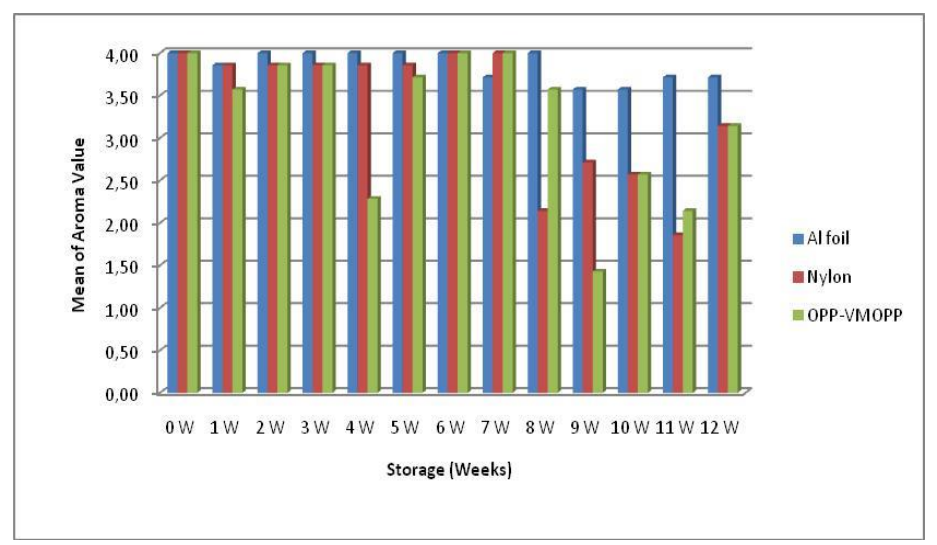

Fig. 3. Average value of instant ganyong yellow rice aroma with 3 types of packaging during 12 weeks storage at room temperature

Table 3. shows instant ganyong yellow rice packed with Nylon at 0 weeks storage until 7 weeks of typical yellow rice aroma, and the aroma changes from 8 weeks storage, to a less distinctive flavour of the yellow rice. Instant ganyong yellow rice packed with OPP-VMOPP at 0 weeks storage up to 8 weeks of flavoured yellow rice and aroma changed from 9 weeks storage to less yellow-colored flavour typi-cal. According to [8] mentions OTR (oxygen transmission rate) Nylon $90 \mathrm{cc} / \mathrm{m}^{2} / 4 \mathrm{hr}$, while OPP $1,500 \mathrm{cc} / \mathrm{m} 2 / 24 \mathrm{hr}$. The combination of OPP with VMOPP proved able to withstand gas and maintain the aroma of the product so that the aroma of instant ganyong yellow rice could be stable up to 8 weeks storage.

Instant ganyong yellow rice packed with $\mathrm{Al}$ foil up to 12 weeks' storage had an average scent value of 3.57-4.00, there is no difference. The aroma of instant yellow ganyong rice were packed with $\mathrm{Al}$ foil with a distinctive aroma of yellow rice. This indicated that the $\mathrm{Al}$ foil packaging was capable of holding the oxygen gas penetrating into the packaging so that the product aroma was stable up to 12 weeks storage. The oxygen from the air entering the package will oxidise the fat/oil from the yellow rice, so the fat is broken and smelly. According to [7] OTR (oxygen transmission rate) of 0-1 $\mathrm{cc} / \mathrm{m}^{2} / 24 \mathrm{hr}$, is very small. 
TABLE III. MULTIPLE COMPARISON TEST RESULTS OF INSTANT YELLOW RICE AROMA WITH 3 TYPES OF PACKAGING FOR STORAGE 12 WEEKS AT ROOM TEMPERATURE

\begin{tabular}{|c|c|c|c|c|c|c|}
\hline \multirow[b]{2}{*}{ Storage Duration } & \multicolumn{3}{|c|}{ Nylon } & \multicolumn{3}{|c|}{ OPP-MVOPP } \\
\hline & Average & Total Ranking & Notation & Average & $\begin{array}{c}\text { Total } \\
\text { Ranking }\end{array}$ & Notation \\
\hline 0 week & 4.00 & 68 & ghi & 4.00 & 69 & ghi \\
\hline 1 week & 3.86 & 63.5 & defghi & 3.57 & 60.5 & cdefghi \\
\hline 2 weeks & 3.86 & 63.5 & efghi & 3.86 & 64.5 & fghi \\
\hline 3 weeks & 3.86 & 63.5 & fghi & 3.86 & 64 & efghi \\
\hline 4 weeks & 3.86 & 63 & bcdefghi & 2.29 & 23 & $a b$ \\
\hline 5 weeks & 3.86 & 63 & cdefghi & 3.71 & 61.5 & defghi \\
\hline 6 weeks & 4.00 & 68 & hi & 4.00 & 69 & hi \\
\hline 7 weeks & 4.00 & 68 & $\mathrm{i}$ & 4.00 & 69 & i. \\
\hline 8 weeks & 2.14 & 16 & $\mathrm{a}$ & 3.57 & 53.5 & bcdefghi \\
\hline 9 weeks & 2.71 & 28 & abcdef & 1.43 & 11 & $\mathrm{a}$ \\
\hline 10 weeks & 2.57 & 22.5 & $\mathrm{a}$ & 2.57 & 31 & abcdef \\
\hline 11 weeks & 1.86 & 14 & $\mathrm{a}$ & 2.14 & 21.5 & $\mathrm{ab}$ \\
\hline 12 weeks & 3.14 & 36 & abcdefghi & 3.14 & 39.5 & abcdefghi \\
\hline
\end{tabular}

\section{Preferences of Yellow Ganyong Instant Rice}

The average value of the organoleptic test in the prexerences of instant ganyong yellow rice with 3 different types of packaging during 12 weeks storage ranged from 1.71 4.00 with the criteria of assessment of preferences there are 4 levels, namely: dislike; do not like it much; Quite like and like. The average value of instant ganyong yellow rice with packed Al foil, Nylon and OPP-VMOPP were 3.75; 3.04 and 3.14. The average value of instant ganyong yellow rice preference packed with 3 different packaging materials at room temperature storage for 12 weeks was presented in Fig. 4.

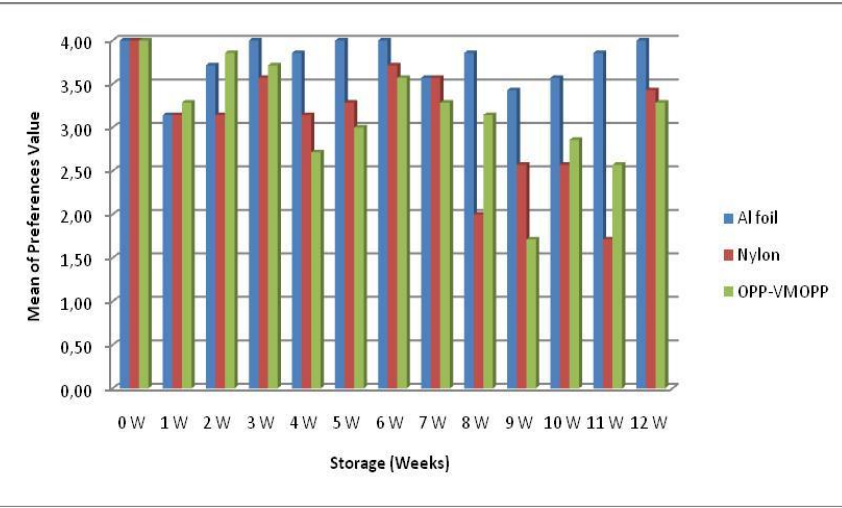

Fig. 4. Average preferences value of instant ganyong yellow rice with 3 types of packaging during 12 weeks storage at room temperature
Friedman test results show that $\mathrm{Al}$ foil packaging type did not give effect to instant ganyong yellow rice preference during 12 weeks storage, while Nylon and OPP-VMOPP packaging had an effect on instant ganyong yellow rice preference during 12 weeks storage at room temperature. The significance value of the Nylon and OPP-VMOPP packaging types is 0.000 . Further test results Multiple Comparison Test to determine differences in the effect of types of packaging material on instant ganyong yellow rice during 12 weeks of storage are presented in Table 4.

Table 4. show that instant ganyong yellow rice packed with Nylon on storage 0 weeks to 7 weeks had preference levels of likes, and the level of preference changed from storage 8 weeks, to less like, but at 12 weeks storage of instant ganyong yellow rice became like. Instant ganyong yellow rice packed with OPP-VMOPP at 0 weeks to 8 weeks storage had a preference level with the criteria for change from 9 weeks storage to less, but at 12 weeks storage the preference level of instant ganyong yellow rice was preferred. Instant ganyong yellow rice packed nylon and OPP-VMOPP up to 12 weeks of storage were both preferred. The distinguishing characteristics of packaging were, transparent nylon packaging so that the packaged product could be viewed from two sides, while OPP-VMOPP could be viewed from one side, in addition to the packaging price. Further [7] mentions in terms of cost Nylon has a high price, while the OPP is classified. Price in nylon packaging market per sheet Rp 980.00 and OPPVMOPP Rp 340.00 per share.

TABLE IV. MULTIPLE COMPARISON TEST RESULTS OF INSTANT YELLOW RICE PREFERENCES WITH 3 TYPES OF PACKAGING FOR STORAGE 12 WEEKS AT ROOM TEMPERATURE

\begin{tabular}{|c|c|c|c|c|c|c|}
\hline \multirow[b]{2}{*}{ Storage Duration } & \multicolumn{3}{|c|}{ Nylon } & \multicolumn{3}{|c|}{ OPP-MVOPP } \\
\hline & Average & Total Ranking & Notation & Average & $\begin{array}{c}\text { Total } \\
\text { Ranking }\end{array}$ & Notation \\
\hline 0 week & 4.00 & 68 & ghi & 4.00 & 69 & ghi \\
\hline 1 week & 3.86 & 63.5 & defghi & 3.57 & 60.5 & cdefghi \\
\hline 2 weeks & 3.86 & 63.5 & efghi & 3.86 & 64.5 & fghi \\
\hline 3 weeks & 3.86 & 63.5 & fghi & 3.86 & 64 & efghi \\
\hline 4 weeks & 3.86 & 63 & bcdefghi & 2.29 & 23 & $a b$ \\
\hline 5 weeks & 3.86 & 63 & cdefghi & 3.71 & 61.5 & defghi \\
\hline 6 weeks & 4.00 & 68 & hi & 4.00 & 69 & hi \\
\hline 7 weeks & 4.00 & 68 & $\mathrm{i}$ & 4.00 & 69 & i. \\
\hline 8 weeks & 2.14 & 16 & $\mathrm{a}$ & 3.57 & 53.5 & bcdefghi \\
\hline 9 weeks & 2.71 & 28 & abcdef & 1.43 & 11 & a \\
\hline 10 weeks & 2.57 & 22.5 & $\mathrm{a}$ & 2.57 & 31 & abcdef \\
\hline 11 weeks & 1.86 & 14 & $\mathrm{a}$ & 2.14 & 21.5 & $\mathrm{ab}$ \\
\hline 12 weeks & 3.14 & 36 & abcdefghi & 3.14 & 39.5 & abcdefghi \\
\hline
\end{tabular}




\section{CONCLUSION}

This type of packaging gives a different effect on the organoleptic properties of instant ganyong yellow rice during 12 weeks storage, including color, shape, aroma and product's preference level. The best packaging was aluminium foil, with the organoleptic criteria of instant ganyong yellow rice: the color was quite yellow, the grainy shape (between grains not sticking together and whole), flavoured yellow rice and preferred. Nutritional content of instant ganyong yellow rice, i.e. $6.48 \%$ protein, $0.66 \%$ fat, $6.42 \%$ water, $0.98 \%$ ash, 36.11 $\mathrm{mg} / 100 \mathrm{~g}$ calcium, $31.24 \mathrm{mg} / 100 \mathrm{~g}$ iron, $14.81 \%$ fiber and $4.82 \%$ inulin.

\section{ACKNOWLEDGMENT}

The author would like to thank The Ministry of Research, Technology and Higher Education of the Republic of Indonesia, which provides funds to carry out research competitive grants in 2016 and the Universitas Negeri Surabaya that has helped fund in following Iconhomecs Seminar 2017.

\section{REFERENCES}

[1] D. Kristiastuti \& R. Ismawati. 2014. Food Processing archipelago. Surabaya. Unpublished.

[2] E. Srihari. 2010. Effect of addition of maltodextrin on the manufacture of coconut milk powder. Journal of Chemical Engineering Department, Surabaya: Faculty of Engineering, University of Surabaya.
[3] L. Sulandari and L.T. Pangesthi. 2015. "Exploration canna (Canna edulis) as a source of inulin in the manufacture of a variety of rice-canna rice for a healthy pre biotic food diversification". Comparative Grant Research Report of $1^{\text {st }}$ Year. Unpublished.

[4] S. Koswara. 2013. Module Processing Technology Tubers. Section 4: Processing Milk ganyong. SEAFAST IPB, (Online, https://seafast. ipb.ac.id/tpc-project/wp-content/uploads/2013/10/4-pengolahanganyong. pdf, accessed October 23, 2015).

[5] P. Luna, H. Herath, S. Widowat, A. B. Prianto. 2015. Effects of Amylose Content on Physical Characteristics and Appearance Instant Rice. Post Harvest Research Journal of Agricultural R \& D Agency, (Online, http://ejurnal.litbang.pertanian.go.id/ index. php/jpasca/article/ view/2442/2110, accessed October 24, 2015).

[6] B. S. Sembiring and T. Hidayat. 2012. The Change of Dry Green Pepper Quality During Storage On Three Types of Packaging and Temperature Levels. Journal of Littri 18 (3), September 2012. p. 115 - 124.

[7] B. Sampurno. 2006. "Polymer Application in Packaging Industry," Indonesian Journal of Materials Science, Special Ed. Pp. 15-22.

[8] R. Arifiani and L. Sulandari. 2015. Effects of ganyong tuber puree (Canna edulis Kerr) substitution towards the organoleptic properties of instant yellow rice," e-journal Boga, vol 5, no. 1, pp. 248-257.

[9] S. Koswara. 2009. Natural Dyes: Production and Utilization. Ebook Pangan. (Online, tekpan.unimus.ac.id/wp-content/uploads/2013/07/ PEWARNAALAMI.pdf..) 